\title{
A SLOW FOOD TERMÉKEK, MINT A VIDÉK VALÓDI ÉRTÉKEI
}

\author{
Dr. Panyor Ágota \\ egyetemi docens Szegedi Tudományegyetem Mérnöki Kar
}

\begin{abstract}
SUMMARY
The primary aim of the international movement which started in the middle of the 1980's in Italy, was to control the effects destroying the traditions generated by the fast-food restaurants and the globalization, and slow down the world. The members of this movement made an appointment about directing the people's attention to preserve the national culture by using traditional foods and foodstuffs, and they are trying to slow down the globalizationed world. In spite of this in our country the movement hasn't spread especially and it doesn't move enough people to participate.
\end{abstract}

Kulcsszavak: Slow Food, globalizáció, lokalizáció, Slow irányzatok, valódi értékek, vidékfejlesztés

\section{BEVEZETÉS}

A mai felgyorsult világban kialakult felpörgetett, hagyományromboló életmód ellen alakult meg a nemzetközi Slow Food mozgalom. Célkitüzései között szerepel az izek újbóli élvezete, a biodiverzitás megörzése, valamint az egy-egy országra, régióra jellemzö termékek, termények, ételek, támogatása és az ezeket elöállító gazdák, termelők segítése. A Slow Food harcol a gyorséttermek, multinacionális vállalatok eluralkodása ellen, a tradíciók, a sajátos népi ételek és a valódi értékek megmentése mellett.

A gyorsétkezdék, a szuper- és hipermarketek, a világ eszeveszett tempója, az élvezetek hajszolása nem ad lehetőséget arra, hogy az emberek hagyományaikban élve, ünnepeiket méltóképpen megtartva, életüket tudatosan élve egy egészséges világot hagyjanak örökül unokáikra. A Slow Food kezdeményezések által kínált programok igyekeznek kialakítani a fogyasztókban egyfajta tudatosságot, mely napjainkban kiveszett az emberekböl. Próbálják az egészséges, nyugodtabb élet felé terelni mindazokat, akik nyitottak a ,régi-új” lehetöségre. A ránk hagyományozott kultúrának, melynek szerves részét képezik az ételek, élelmiszerek, és a hozzá tartozó tradíciók a vidék valódi értékeként kell megjelenniük.

\section{A SLOW FOOD MOZGALOM KIALAKULÁSA ÉS IRÁNYZATAI}

\subsection{A Slow Food mozgalom kialakulása}

A Slow Food, vagyis „lassú ételek”, „komótos evés” egy nemzetközi mozgalom neve, mely az étkezésbeli igénytelenséggel, a gyorséttermek eluralkodásával szemben alakult ki. Ezen nemzetközi ökogasztro mozgalom zászlaján egyszerre szerepel a jóizü étkezés, a természetes fajtagazdagság megőrzése és a helyi termelők támogatása. Az izérzés és a hagyományok védelmében kötődik a tradicionális ünnepekhez. Az egyedit, a különlegeset, a helyit segit visszaforgatni a mindennapi életbe, megmenteni a kihalásra ítélt élelmiszertermékeket, segit a vállalkozásoknak és óvja a hagyományokat.

1986-ban alakult meg Olaszországban az Arcigola, melyet a Slow Food előszervezeteként tartanak számon. Az Arcigola fö célja és kialakulásának konkrét oka az volt, hogy megakadályozza a McDonald's megnyitását Rómában, közvetlenül a Spanyol lépcső mellett. A mozgalom fejének, Carlo Petrininek e gyorsétterem megnyitásának okán sikerült valódi népfrontot összekovácsolnia a parttalan globalizáció ellen, ugyanis számíthatott mind a környezetvédők mind az értékmegőrzők segítségére. 
A szerveződés központja az olaszországi Bra városa. A szerveződés 1989. november 9-én Párizsban tartott nemzetközi találkozót, amely összejövetel a nemzetközi mozgalom hivatalos kezdetét jelentette, és 15 ország képviselöi fogadták el a mozgalom kiáltványát. Az Arcigola nemzetközi mozgalommá alakult és ettől kezdve már Slow Food néven müködött tovább. A találkozón aláirásra került egy ún. manifesztum, azaz kiáltvány, mely az ,ízekhez való alapvető jogunkat" foglalja magába.

A kezdeményezés állandó jelképévé váló kiscsiga megtalálható szinte minden formában a Slow Food mellett (1. ábra).

\section{1. ábra: Slow Food jelképek}

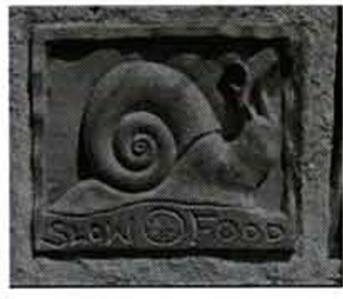

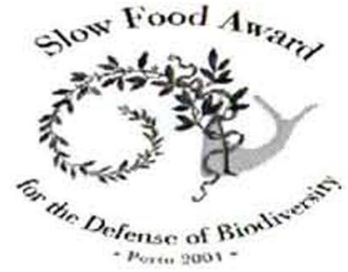

Forrás: www.slowfood.com

Közel 70 ezer ember részvételével konviviumok (alapszervezetek) alakultak 48 országban. A lassú mozgalom folyóiratot hozott létre, mely öt nyelven jelenik meg Slow néven.

\subsection{A különböző Slow irányzatok megjelenése}

1999-ben World Institute of Slowness néven került megalapitásra egy világszervezet. A kezdeményezés Geir Berthelsen érdeme, akinek alapgondolata szerint a világon eluralkodó gyorsulási folyamatot nem generálják sem biológiai, sem társadalmi igények. Sőt állítása szerint a fogyasztó szeretne ismét ember, utazó, vendég lenni, régi vagy új emberi kapcsolatokat megélni és gyönyörködni a különböző művészetekben. A történtek alapján ez a feltételezés nagyon is helytálló, mivel a világintézet 10 évvel ezelötti alapítása óta a lassitás filozófiájára számos „Slow mozgalom” épült és hirdeti a komótos élet ideológiáját.

\section{Ezek a következök:}

- Slow Travel: Lényege, hogy a nyaraló egy adott helyen töltsön minél több időt a környék és a helyi közösség megismerésével. Szállás esetén a lényeg az önellátás, szóba jöhetnek a farmok vagy a sátorozás.

- Slow Design: A bútorok, ruhák vagy ékszerek tervezöi természetbarát anyagokat használnak termékeik elöállításához. A legismertebb slow designerek a brit Alastair FuadLuke és az izlandi Thorunn Arnadottir.

- Slow Reading: A lassú olvasás, melynek célja a kikapcsolódás mellett a szövegben való elmélyedés, továbbá kiemelik a helyi irodalmi fórumok, események jelentőségét.

- Slow Exercise: A lassú mozdulatokon és mentális elmélyülésen alapuló sportok, mint a jóga vagy a tai chi tartoznak ide.

- Slow School: Más néven lassú oktatás. A Montessori- és a Waldorf-pedagógia módszerek a mérvadóak, melyek figyelembe veszik a gyerekek egyéni tempóját és sajátosságait, illetve nagy hangsúlyt fektetnek a környezettudatos nevelésre és az ökológiai tudatosság kialakítására. 
- Slow City: Nyugodt városnak fordíthatnánk a megmozdulást, melyet 1999-ben négy olasz kisváros: Bra, Greve in Chianti, Orvieto és Positano alapitott és napjainkra már a világ 16 országának 120 városát tömöríti magába. A csatlakozás célja, hogy az adott település ellen tudjon állni az erőszakos fejlesztéseknek, a környezet kizsákmányolásának, valamint lehetöleg ne vesszen el és ne váljon középszerüvé a globalizálódó világban.

- Slow Work: A lassulás filozófiája elérte az irodákat és a menedzservilágot is. Régóta ismert tény, hogy a dolgozók relaxáltsága jó hatással van a teljesítményükre, ezért sok vállalatnál egyre nagyobb figyelmet fordítanak erre. Napjainkban a kommunikációs technológia „megzabolázásával” próbálják a munkatársak produktumát növelni. Felhívják a kollégák figyelmét, hogy amikor csak lehet, kapcsolják ki mobiltelefonjukat, esetleg próbálják meg minél kevesebbszer megnézni az e-mailjeiket egy nap. A ,lassú munka” a kreatív tevékenységeket támogatja, és inkább az olyan területeken fontos, ahol a hatékonyságot nem a munkával töltött órákban mérik, hanem a hasznositható ötletek mennyiségében.

- Slow Money: A magát a jövő gazdasági példaként hirdető projekt a helyi farmokba, gazdaságokba való befektetésre buzdit. A programban részt vevők fontosnak tartják, hogy a befektetők közvetlen kapcsolatban álljanak azzal, amibe invesztálnak, ezért összehozzák a beruházót a termelőkkel, hogy megismerjék egymást.

A nagyszámú ,slow irányzat" közös célja az élhető környezet, a helyi közösségek szerepe és az autentikus élményekben való elmerülés (Zsély, 2009).

\section{A SLOW FOOD SZEREPE A GLOBALIZÁLT VILÁGBAN}

Eugen Briffault francia író már 1846-ban megmondta, hogy ,egy nép konyhaművészete civilizációjának egyetlen pontos ismérve". Az ételek, az élelmiszerek összefonódnak a kultúrával, a hagyományokkal, a szokásokkal. Így a globalizáció hatására megváltozott termékek módosítják az ösi szokásokat, átalakítják a hagyományokat, átszervezik a megszokott életmódot. A világ homogenizálódása a helyi értékek eltünését vonja maga után, amely pótolhatatlan biológiai és kulturális veszteségeket okoz. Kultúrák, értékek, hagyományok, ünnepek, érzelmek, örömök és emberi kapcsolatok merülnek feledésbe, ,gazdasági sikerek" okán.

\subsection{A gazdaság lokalizálásának jelentősége}

Jellemezően nem tudunk hatni a globális világra, nem tudjuk befolyásolni a gazdasági törvényeket, a tőkemozgásokat, a nagy áruházláncokat. Irányíthatjuk viszont azokat a dolgokat, melyek eleve nem globálisak. A világ érdeklődő, az emberek fogékonyak a különlegességekre, a vidékre, a városokra, falvakra, a kultúrákra, a nevezetességekre, a helyi gasztronómiákra. Kiemelten kell törekednünk a valós értékek kialakítására , a helyi értékek feltérképezésére és kiaknázásával. Így fontos cél a lokalizáció, amely a globalizációt hivatott ellensúlyozni. A lokális folyamatok szinterei a régiók, a megyék, a kistérségek és a települések. A vidék minden szegmensét áthatja a helyi szinten megjelenő, valódi értéket képviselö helyi termékek köre.

A helyi értékek, gyümölcsök, zöldségek, sajátos termékek, egyedi élelmiszerek és a tájjellegü termékek soha nem a szupermarketekben keresendők. A hagyományos termékek értékesítésénél a legföbb probléma, hogy nem fizetnek érte annyival többet, mint amennyivel több időt, törődést fordítottak rá. A különböző gasztronómiai programok, fesztiválok esetében a munkaerő rendszerint a lelkesedésen alapul, nem függ a munkabértől. Ilyen alkalmakkor gyakorta ingyen dolgoznak az emberek. Az ilyen programok alkalmával életre kel a turizmus, felhasználásra kerülnek a hagyományos termékek, újjáélednek a helyi legendák és tradíciók. Mindez óriási tömegeket vonz, és ezáltal a haszon is jóval jelentősebb, mint amennyi a 
fesztivál alapjául szolgáló termékböl (például halászlé, kocsonya, dinnye...stb.) kihozható (Erdős, 2004/b).

\subsection{Lassú ételek, mint a vidék valódi értékei}

A globalizáció kulturális hatásai leszoktatják az embereket a hagyományaikról, a valós értékeikröl. A nemzetközi Slow Food mozgalom számos országban a „globalizáció lokalizáció" egyensúlyának kialakitására törekszik. A mozgalom több országban, rengeteg résztvevővel, helyi csoportokkal müködik. Ezen csoportok nemzetközi együttmüködése, a lokális értékek követése ismertséget, elismerést, piacot teremt, és ezzel akaratlanul is ellensúlyozza a globalizáció egységesítő hatását. A lassú étel egyenlő az izekkel, hagyományokkal, érzékeléssel, ünnepekkel, kikapcsolódással, emberi kapcsolatokkal, valós érzelmekkel. A lassú étel komótosabb életvitelre utal. A Slow Food kapcsán sorra születnek a sajátos, a helyi világhoz visszafordító események, könyvek, bemutatók, védett terméklisták, kiállítások, fesztiválok. A mozgalom kihalásra itélt termékeket ment meg, elfeledett ízeket hoz vissza, és teszi őket szélesebb körben ismertté. Óvja a hagyományokat és segíti a helyi vállalkozásokat, növeli a vidéki területeken élők életminőségét, fejleszti a vidék gazdaságát.

\section{SLOW FOOD HAZÁNKBAN}

A lassú életvitelre ösztönző csiga mozgalom nem egy szük elitet céloz meg. Tömeges mozgalom, mely hazánkban is egyre bővülő társaságokat eredményez.

A Slow Food mozgalomnak Magyarországon jelenleg tíz csoportja müködik, és továbbiak alakulása várható. Az egyes csoportok tagjai és vezetői elkötelezetten vallják a Slow Food elveit, és igyekeznek hazánkban is minél nagyobb érvényt szerezni a mozgalomnak (Erdős, 2004/a). Programokat, rendezvényeket szerveznek, melyekben kölcsönösen segítenek, és amiket kölcsönösen látogatnak az amúgy külön álló társulások. Egy-egy csoport erősen kötődik az általa rendezett programokhoz. De vannak közös rendezvények is, melyeken a csoportok összessége részt vesz. A nemzetközi találkozásra pedig a Salone del Gusto kiállitás és a Terra Madre találkozó ad lehetőséget.

\subsection{A Slow Food csoportok, mint a valódi érték megőrzői}

Hazánk rendkivül jó adottságokkal rendelkezik, a gyümölcs-, zöldségtermelés, valamint az állattenyésztés, a borászat területein, és ezeknek az áruknak a termelése, elöállítása hosszútávú hagyományokon alapul. A tradíciók továbbadása pedig egyenlö a kultúra megörzésével. A magyar slow csoportok a vidéki területek helyi termékeit, hagyományokra épülö kultúráját és valódi értékeit helyezik tevékenységük középpontjába.

Magyarország legrégebbi Slow Food tömörülése a Budapesti Vendég-kör. Kiemelt szerepet szánnak a boroknak és azoknak a szervezetre gyakorolt jótékony hatásuknak. Adott helyi, hagyományos élelmiszereket és füszereket kóstolnak össze borokkal, majd megállapítják a legjobb étel-italpárosításokat.

A Civis Konvivium az Észak-alföldi régió központjában, Debrecenben alakult. A konvivium nem csak az értékek megóvását, hanem azok színvonalas bemutatását is célul tüzte ki. Ebben nagy szerepet kap a helyi vendéglátó kultúra, az alföldi nép hagyományai, a térség ízeinek ápolása és megörzése.

A Régi Jó Ízek Barátai konvivium Budapesten egyesíti azokat, akik pártolják a hagyományos élelmiszereket és szívükön viselik azok sorsát. A társaság két fỏ tevékenységi körrel rendelkezik. Az egyik a hagyományos mezögazdasági termékeket és élelmiszereket, valamint 
az erre épülö gasztronómiát öleli fel. A másik aktivitási terület fö profilja a termelö közösségek és a termékek támogatási formáinak fejlesztése, ezáltal segitve az ismeretségük növelését, az egészségtudatos táplálkozásra ösztönzését.

A Szatmári Ízek Barátai konviviumot a Felső-Tisza vidékén élők sajátos kapcsolata hozta létre, abból a célból, hogy termékek, termények, ételek, italok és kultúrák fennmaradjanak eredeti, hagyományos minőségükben. A konvivium Penyigei csoportja mellett még számos település (Panyola, Szatmárcseke, Milota, Túristvándi, Kölcse, Tiszakóród) kap aktív szerepet a csoport életében, a hagyományos, helyi ételek megőrzésében.

A Kiskunsági Hagyományok Baráti Kör (Kunpuszta) tagjai kiemelt feladatuknak tekintik, hogy az érdeklődőket megismertessék a térség ízeivel, a hagyományos fözési technikákkal és a biotermeléssel. A csoport tagjai nem csak ízlelik a kiváló ételeket, hanem meg is termelik az alapanyagokat hozzá. Kiemelt tevékenységi körük a biogazdálkodás, melynek során biozöldségkrémeket, bio-italokat, gyógynövényeket, bioborokat, biomézet, és különböző mangalica termékeket állitanak elö illetve ismertetnek, kóstoltatnak hazai és nemzetközi rendezvényeken egyaránt.

A Baranyai Ízek Asztaltársaságának fö célkitüzése az étkezés rangjának visszaállítása a helyi élelmiszerekkel, a helyi értékekkel. A Magyar Nemzeti Gasztronómiai Szövetség pécsi képviselöi által összegyüjtött ősi recepttúrák jó alapul szolgálnak a tradicionális ételek elkészítéséhez.

A Tisza-mente akciócsoport (Szolnok) legjelentősebb szerepet a hagyományőrzésben vállalja. Számos rendezvény keretében otthont adnak hagyományőrző, gasztroturisztikai bemutatóknak továbbá helyi termékek ismertetésének és vásárának.

A Slow Food Tokaj Convivium céljai közé sorolható az izmühelyek és a szakmai kóstolók szervezése. Mindezek mellett fontosnak tartják, hogy a gasztronómiával már a gyerekek is megismerkedjenek, ezért iskolai programokat is szerveznek.

A Slow Food Convivium Pécs Pannónia konvivium céljai közé tartoznak a hagyományos ételek újrafelfedezése, a tájjelleg és a biodiverzitás megőrzése mellett az új konyhatechnikák megismerése. A szervezet tagjai többnyire magánemberek, és önkéntes munkában segítik a csoport müködését Pécsen, és „lassítják” egy kicsit a régiót.

A Palóc Ízek Konvívium székhelye Kozárd. A falu híres kiváló gyümölcseiröl, melyekből aszalt termékeket, természetes gyümölcsleveket, a „Palóc izek” sorozat lekvárjait és kitűnő minőségü pálinkát állitanak elő. A település munkát biztosít több környékbeli faluban élöknek is, valamint a fejlesztéseknek köszönhetően a tradicionális kozárdi értékekre építve fejlődik a turizmus is.

\subsection{A konviviumok közös célkitüzései a vidék valódi értékeinek megőrzésére}

Minden konvivium hasonló célok mentén alakult, és ezek a célkitüzések megteremtik a közös gondolkodásmódot és a közös célok kialakítását:

- Szeretnék fejleszteni a fogyasztók étkezési kultúráját, a táplálkozásbeli igényességüket, és fokozni az íz-érzékelésüket illetve a termékismeretüket.

- Segítik bőviteni a szakemberek tájékozottságát, szakmai felkészültségét. Hozzásegítik a hozzáértőket és az érdeklődőket további izlelés-kultúra információkhoz.

- Ápolják a magyar hagyományokat, melyek rendszerint kötődnek a hazai izekhez (ételek, italok, termékek).

- A még fellelhető, de mára már feledésbe merült fajták, termékek, receptek felkutatása, rögzítése, újbóli népszerüsítése. 
- A hazai gasztronómia és borkultúra hirnevének további öregbitése és jövöjének elősegitése.

- A hagyományok, a népi kultúrák, a mezőgazdasági és termelöi életmódok és értékek gondozása.

- A népművészeti értékek, a hazai tájak megóvása és ismertségének elősegitése.

- A Hagyományok, Ízek, Régiók (HÍR Program) sikereihez való eredményes hozzájárulás (Erdős, 2004/c).

\section{4. ÖSSZEFOGLALÁS}

A publikáció témája a napjainkban jellemző mindennapos kérdésekre és problémákra keresi a választ, a megoldást. Az egyre gyorsabb ütemben fejlődő világ közös problémái közé tartozik, hogy a fejlődés összemossa a nemzetek kultúráit, a szabad piacgazdálkodás révén pedig egyes országok (mint ahogyan Magyarország is) piaci részesedésüket fokozatosan elveszitik. Ezen problémákra kínálnak lehetséges megoldásokat a Slow Food termékek, melyek a kulturális sokszinűség megőrzésére, a hazai termékek és gazdák védelmére, de mindenekelőtt az ízek érzékelés-örömeinek újbóli megtanítására hivatottak. Kiemelten fontos az egyedi, egy adott földrajzi helyre jellemző ételek, élelmiszerek, kultúrák megőrzése és megismertetése más környezetből érkezőkkel. Továbbá kiemelendő az étkezésbeli sokszinűség megtartása és a biodiverzitás, mindezek mellett pedig a hagyományok, a kialakult szokások megóvása.

„A lassú étel iz, hagyomány, ünnep, kikapcsolódás. Ott a helye, bármilyen ritkán is, az emberek életében" (Erdős, 2004/d).

\section{IRODALOMJEGYZÉK}

Erdōs Zoltán (2004/a): Élelmiszerek, ételek és a globalizáció l., Élelmezési Ipar, 58. évf. (1) 2-4.

Erdős Zoltán (2004/b): Élelmiszerek, ételek és a globalizáció II. - Slow Food = A "lassú étel” mozgalom, Élelmezési Ipar, 58. évf.(2) 38-41.

Erdōs Zoltán (2004/c): Élelmiszerek, ételek és a globalizáció III. - Hatások és tendenciák, Élelmezési Ipar, 58. évf.(3) 65-70.

Erdôs Zoltán (2004/d): Élelmiszerek, ételek és a globalizáció IV. - Lehetőségek, Élelmezési Ipar, 58. évf. (4) $97-101$.

Zsély Anna (2009): Lassítósáv- Slow mozgalom, Figyelö, 53.évf., 36-37.

www.slowfood.com 